\title{
IMPROVING LOGISTICS DISTRIBUTION THROUGH TRANSPORTATION INFRASTRUCTURE DEVELOPMENT IN GREATER JAKARTA
}

\author{
Bambang Susantono, Mohammed A. Berawi ${ }^{*}$, Perdana Miraj, Jade S. Petroceany \\ Center for Sustainable Infrastructure Development, Faculty of Engineering, Universitas Indonesia 16424, \\ Indonesia
}

(Received: December 2014 / Revised: January 2015 / Accepted: February 2015)

\begin{abstract}
The Greater Jakarta Industrial Area is the biggest contributor of Indonesia's exported goods, hence logistics distribution from and to this area are becoming increasingly critical. Tanjung Priok Port and Soekarno-Hatta Airport are two transport systems that support this area's logistics distribution. However, problems including overcapacity of Tanjung Priok Port and Soekarno-Hatta Airport, as well as dependency on roads to transport cargo, lead to decrease national logistics performance. This paper presents a transportation infrastructure development scenario to support the logistics and supply chains of the Greater Jakarta Industrial Area, which will eventually raise the national competitiveness level to compete in the global and regional markets. The scenario will be developed based on various data analyses, including Greater Jakarta's logistics data, as well as infrastructure capacity and predicted demand. Meanwhile, the transportation infrastructure would include the development of multiple-ports, multiple-airports, as well as road and railway connectivity.
\end{abstract}

Keywords: Airports, Infrastructure, Logistic Distribution, Ports, Transportation

\section{INTRODUCTION}

Logistics involve the management of the movement of resources from the production line to the hands of consumers (Jayaraman et. al, 1999; Rushton, 2010). In order to distribute goods into the final destination, the logistics of physical items involves the integration of several activities including production, material handling, packaging, inventory, warehousing and transportation (Stock et. al, 2000; Giaglis et. al, 2004; Kasilingam, 1998). Transportation has been recognized as one of the most important activities in the physical distribution function at $46 \%$ followed by warehousing (22\%) and $22 \%$ for inventory carrying costs (Rushton, 2010). Hence, fast and reliable transportation modes are required to maintain good services for logistics distribution.

Greater Jakarta is a megapolitan city with 28 million of population that needs transportation infrastructure development designed to serve the demand of passenger and goods flow of the city. Currently, the Greater Jakarta Industrial Area handles up to $45 \%$ of exported goods volume and $70 \%$ of exported goods value from Indonesia. There are two transport systems in order to export goods from this area: first, by marine transport through Tanjung Priok Port and second, by air transport through Soekarno-Hatta Airport.

Tanjung Priok Port is the largest and the busiest port in Indonesia located in North Jakarta and largely serves the Greater Jakarta Industrial Area. Accessibility to the Tanjung Priok Port from the industrial area mainly relies on the Jakarta-Cikampek Toll Road.

\footnotetext{
Corresponding author. E-mail: maberawi@eng.ui.ac.id
} 
Seventy-percent of the traffic volume of heavy vehicles to Tanjung Priok Port comes from the industrial area [6], which places a considerable burden to the Jakarta-Cikampek Toll Road, resulting in serious congestion in most of the toll roads in Jakarta, including the intercity and ring road toll roads, which are the main access to and from the airport. On the other hand, railway infrastructure linking the city to Tanjung Priok Port has not been completed.

Moreover, Indonesia's international logistics also rely on the Soekarno-Hatta Airport, whose current demand is already twice as much as the existing capacity. As a result, Greater Jakarta's transportation infrastructure suffers from high demand exceeding its current capacity. This paper is expected to produce a transportation infrastructure development scenario to support the logistics and supply chains of the Greater Jakarta Industrial Area in order to enhance national logistics competitiveness.

\section{METHODOLOGY}

In order to achieve research objectives, this paper will use a case study approach. A case study normally focuses on one case, but simultaneously takes into account the context and so it encompasses many variables and qualities. Furthermore, this method is appropriate to analyze specific events in a certain place as well as at a certain time (Bassey, 2003). This paper examines the Greater Jakarta Industrial Area as a single case study, since substantial goods export occurs in this area, hence improving its logistics distribution capacity which is expected to enhance national economic development.

There are several sources of data collection in a typical case study, including documentation, archival records, interviews, direct observation, participant observation and physical artifacts (Tellis, 1997; Vissak, 2010). In this paper documentation such as research reports and archival records, such as maps, chart and survey data, are being used for data collection. Based on the data collection, elaboration of the government's strategic steps is conducted in order to improve logistics distribution.

\section{GREATER JAKARTA PROFILE}

Greater Jakarta has experienced significant population growth in its metropolitan area, ranging from 8.4 million in 1970 to 28 million in 2010. As individuals flock to work and live in the capital, transport movement has also grown over the years. In the last 20 years, Greater Jakarta has faced enduring and complex transport and traffic problems, which can be witnessed by heavy traffic congestion in main roads, inadequate public transport, as well as inefficient and disintegrated transport supporting systems.

The population of Jakarta's suburbs rose by $50 \%$ between 2002 and 2010 . As a result, the number of trips from the suburbs to the city has grown considerably. There were 743,000 commuter trips per day from the suburbs to the city in 2002. This figure has grown about $50 \%$ into 1.1 million trips in 2010. At the same time, the distance travelled by commuters also increased by 43\%, from $6.7 \mathrm{~km}$ in 2002 to $9.6 \mathrm{~km}$ in 2010 (JICA, 2011). As a result, urban transportation problems, such as traffic congestion, are worsening in the Greater Jakarta metropolitan area.

Not only do Jakarta's roads carry the burden of urban transport, but also they receive immense pressure from freight transport over the years. Tanjung Priok Port is the biggest port in Indonesia with a total of 78 ships docked and 14 container ships. Container flows through Tanjung Priok Port up to December 2011 was predicted to reach 6 million Twenty-foot Equivalent Units (TEUs) which surpassed its capacity by around 5 million (TEUs), therefore, it is predicted that Tanjung Priok Port would not be able to serve the projected container load growth rate of 1.3 million TEUs /year in the next few years, as can be seen in Figure 1. 


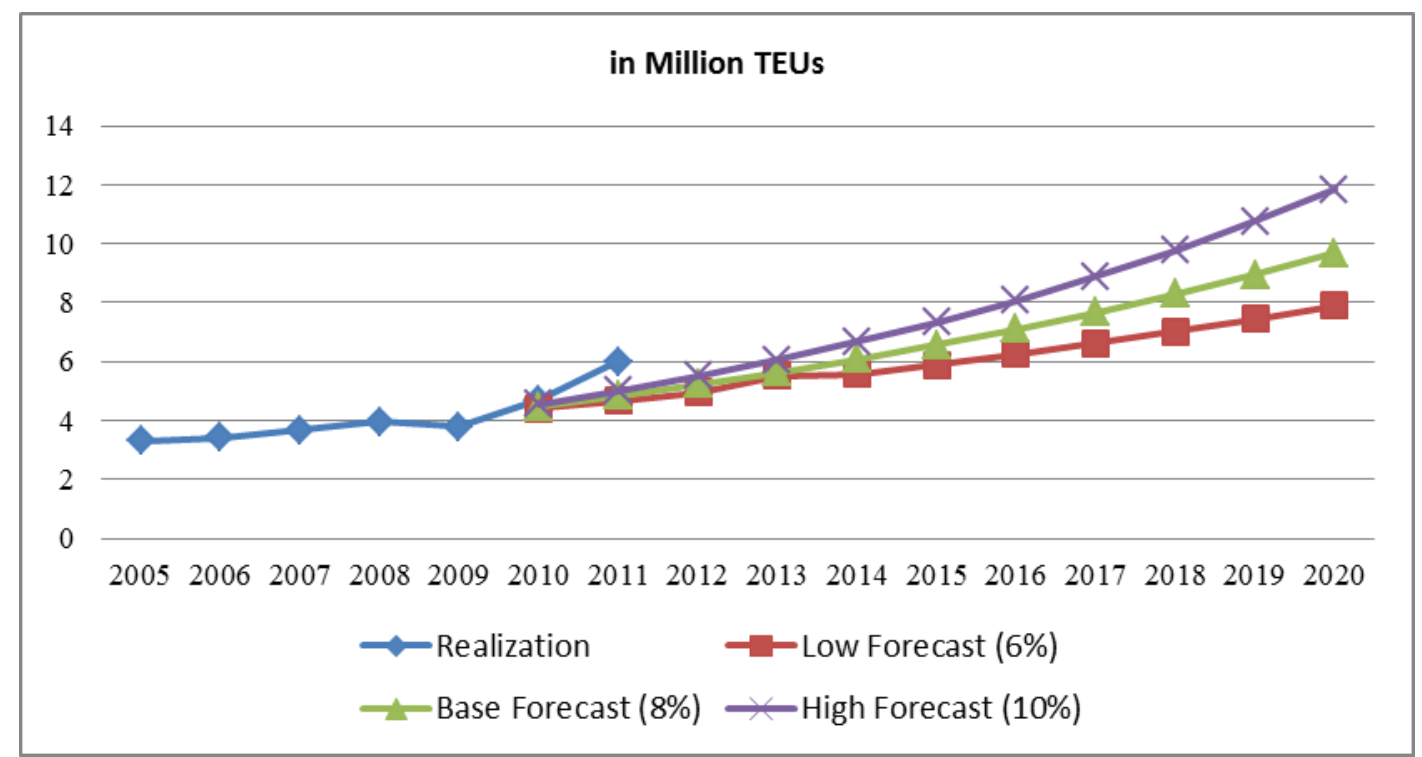

Figure 1. Container Traffic in Tanjung Priok Port

Adopted from : David Wignal Associates, 2009

Furthermore, development of transport cargo in the world is currently at a level of about $80 \%$ being transported by containers. With the continually increasing capacity of ships from 1,500 TEUs to 9,000 TEUs, a berthing depth at least 13 meters is required. Hence, when comparing Tanjung Priok Port's ship container capacity, which is below 6,000 TEUs with other world-class ports of around 9,000-12,000 TEUs, Tanjung Priok Port would not be able to compete. In order to accommodate cargo and vessel needs, Indonesia has to increase its port capacity, including the construction of international hub ports.

At the same time, the cargo services in Indonesia's main airport, Soekarno-Hatta International Airport, could not handle the current demand. The cargo handling volume of Soekarno-Hatta International Airport in 2010 was 497 thousand (Metric Tons) MT in total (JICA, 2012a), almost half of which is international cargo and the rest is domestic cargo. Currently, the cargo volume realization has reached twice the existing capacity. With the assumption of cargo growth of $8.1 \%$ per year, in 2016 the cargo volume will exceed four times the existing capacity in the do-nothing scenario.

\subsection{Greater Jakarta Industrial Area}

There are 68 industrial estates, excluding projects that are under construction, in the Greater Jakarta Industrial Area and about $63 \%$ of them (42 estates) are located in the eastern area (Bekasi and Karawang) of Greater Jakarta which is illustrated in Table 1, (HKII, 2012) .

Table 1. Distribution of Industrial Land in the Greater Jakarta Region

\begin{tabular}{ccc}
\hline No & $\begin{array}{c}\text { Distribution of } \\
\text { Industrial Land }\end{array}$ & Percentage \\
\hline 1 & Bekasi & $33 \%$ \\
2 & Bogor & $7 \%$ \\
3 & Jakarta & $6 \%$ \\
4 & Karawang & $30 \%$ \\
5 & Tangerang & $24 \%$ \\
\hline
\end{tabular}

With more than $40 \%$ of the overall industrial estates located in eastern Jakarta, automotive and related industries remained the key drivers for industrial logistics flows. The 
automotive sector contributes around 58,6\% of total logistics distribution flows, meanwhile other industries' contributions are below $26 \%$ as can be seen in Table 2 (Colliers International, 2012). Furthermore, a number of independent factories, which are not within the industrial estates, have gathered around the Soekarno-Hatta International Airport.

\begin{tabular}{lll}
\multicolumn{3}{c}{ Table 2. Type of Industries Contributor } \\
\hline No & $\begin{array}{c}\text { Industrial Sector } \\
\text { Contributor }\end{array}$ & Percentage \\
\hline 1 & Automotive & $58,6 \%$ \\
2 & Oil \& Gas & $5,9 \%$ \\
3 & Developer & $5,5 \%$ \\
4 & Logistic & $4,1 \%$ \\
5 & Others & $25,9 \%$ \\
\hline
\end{tabular}

The distance from Soekarno-Hatta International Airport and Tanjung Priok Port to major industrial estates and tenants in the eastern area are on average $70 \mathrm{~km}$ and $50 \mathrm{~km}$ respectively. There are about 3,200 companies located in major industrial estates in Greater Jakarta Industrial Area, mainly located in the eastern side of Greater Jakarta. The industrial area has a tendency to keep growing to the eastern part of Greater Jakarta, as it has become too expensive to expand one's business in the center of Greater Jakarta.

\subsection{Current Logistics Flow Distribution}

Accessibility to Tanjung Priok Port and Soekarno-Hatta Airport from the industrial area mainly relies on the road transportation system, including non-toll road access plus intercity and ring road toll roads. Since road links in almost all of thr Greater Jakarta area have reached their capacity levels, using road transportation would result in more serious congestion, hence reduced road pavement durability and inefficiency in terms of timely delivery. Creation of other reliable transportation systems is required to connect the industrial area of Greater Jakarta to Tanjung Priok Port and Soekarno-Hatta Airport.

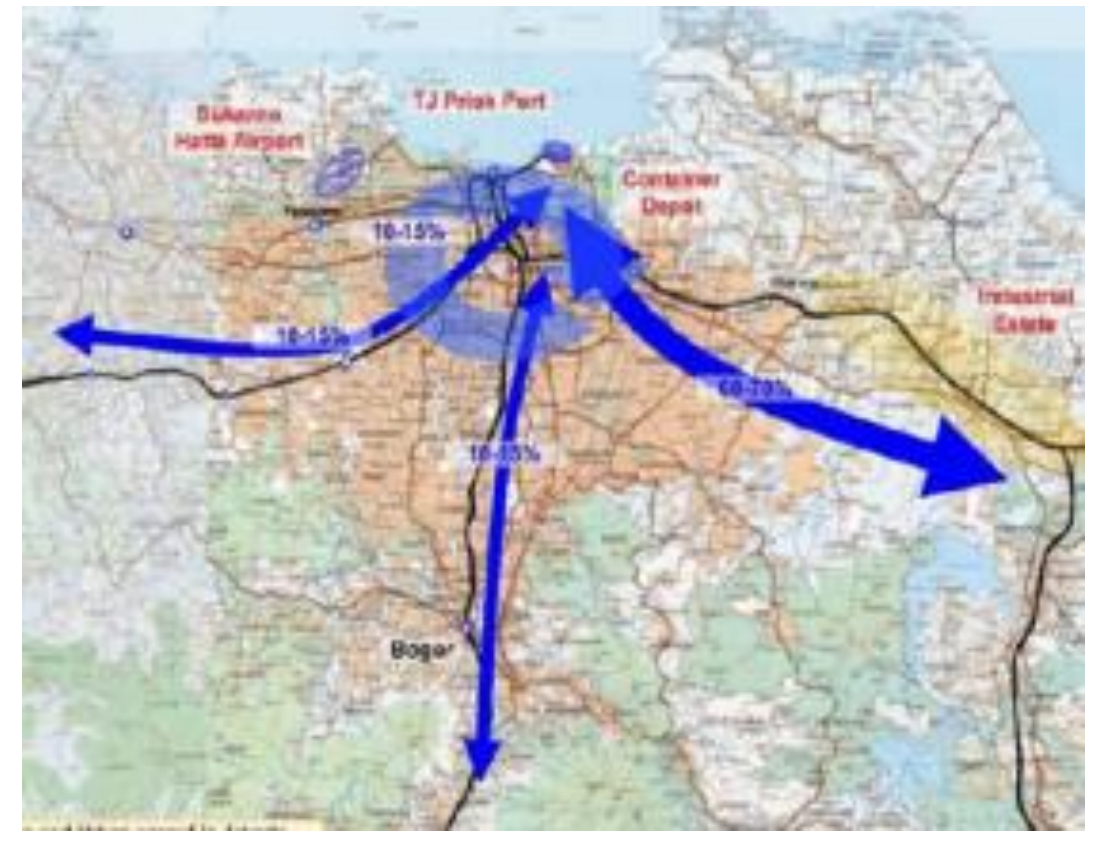

Figure 2. Cargo Flow to Tanjung Priok Jakarta 


\section{DISCUSSION}

The Government of Indonesia is introducing policies that aim to reduce the transport burden on roads. The burden is to be shifted and balanced by other modes of transport, i.e. railways and short-term sea shipping lanes. In the case of Greater Jakarta, the available options will be the improved railways.

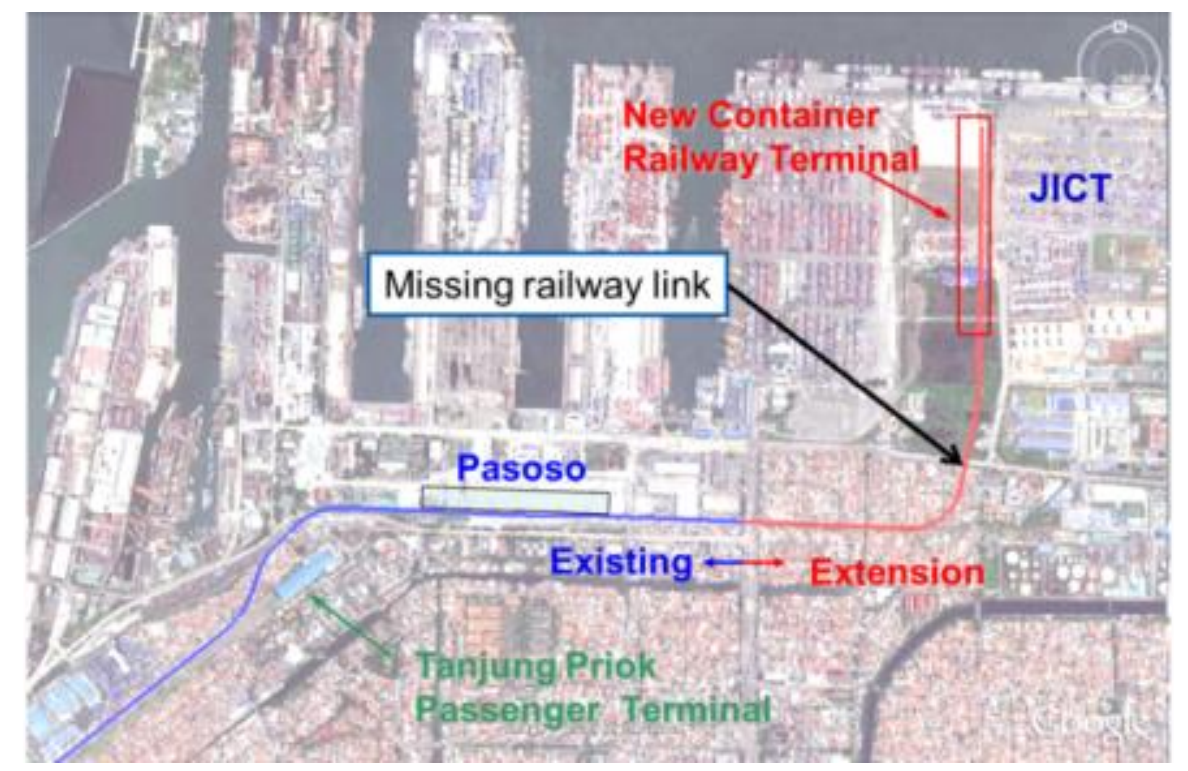

Figure 3. Rail Infrastructure in Tanjung Priok Port

One example of how the railway is used for freight transport is the Cikarang Dry Port Railway going to Tanjung Priok Port. Cikarang Dry Port acts as an extension gate of the Tanjung Priok International Port. The idea is to bring a port to the heart of the industrial manufacturing area, which will serve both as a port of origin and a port of destination. However, there is still a missing link in the railway system in Tanjung Priok Port area. Trains from Cikarang Dry Port are still unable to reach Tanjung Priok Port because the railway from Pasoso station to the Jakarta International Container Terminal (JICT) in the Tanjung Priok Port is not yet available, as can be seen in Figure 3.

Greater Jakarta (Jabodetabekjur) is a megapolitan city which needs progressive development of its transportation infrastructure designed to support the logistics and supply chains of the Greater Jakarta, which will eventually raise the national competitiveness level to compete in the global and regional markets.

Since Greater Jakarta's industrial area has progressed quite rapidly, there is an urgent need to develop new transport infrastructures to help improve the distribution of logistics to fulfill the growing demand. The scenario for transport infrastructure development includes the development of multiple ports, multiple airports, as well as road and railway connectivity improvement.

In terms of railway connectivity, it is an important step in an effort to improve the container transport as well as to shift the transport burden away from Greater Jakarta roads. In the first phase, a railway link connecting Cikarang Dry Port to the Pasoso Station, located $2 \mathrm{~km}$ away from Tanjung Priok Port, will be built. In the second phase, another link from Pasoso Station to the Jakarta International Container Terminal (JICT) in Tanjung Priok Port will be completed.

As the logistics demand in Tanjung Priok Port is expected to reach its capacity in 2014 (JICA, 2010), it is projected that the container demand in 2030 will reach 2-4 times the capacity provided in 2014. The Government of Indonesia is exploring all possible avenues to 
improve the capacity of Tanjung Priok Port. There are several possible ways to expand the capacity of Tanjung Priok Port: (a) optimization of the existing capacity of the port, (b) development of a new terminal, and (c) development of a new port in another location which will be able to cater to the container throughput growth up to 2030.

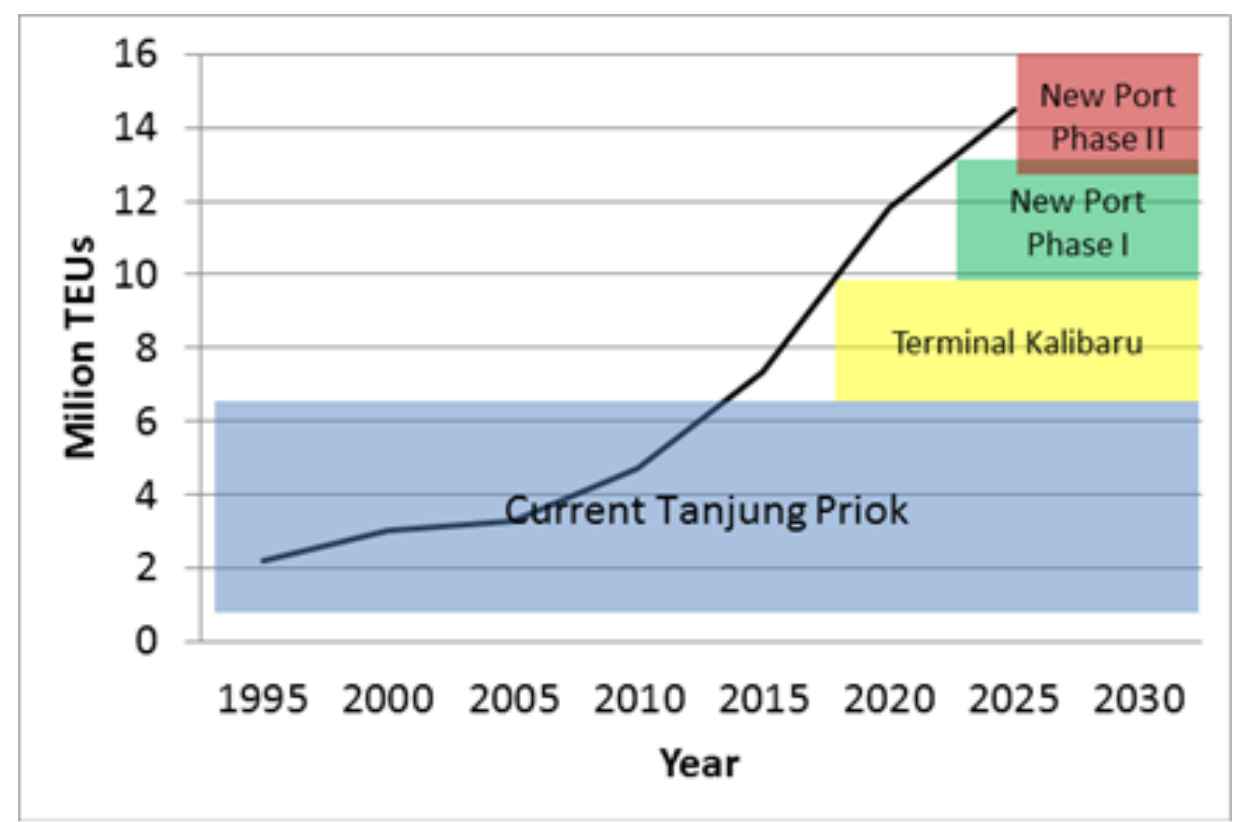

Figure 4. Container Cargo Demand Forecast and Capacity

The development of a new terminal called Kalibaru Terminal is currently in a tender process. When this terminal is completed, it will be able to serve the container logistics demand until 2019. Before the port capacity is reached in 2019, there is an urgent need to expand the capacity even further through the development of a new port in another location.

A study on the Master Plan of Tanjung Priok Port has been completed. It has considered the traffic analysis, dredging maintenance, distance to the industrial area, coastal line changes, ecological effects and other environmental factors. The result of this study suggests that Tanjung Priok Port capacity expansion should be further supported by the development of another port in Cilamaya, $\pm 60 \mathrm{~km}$ in the eastern part of the port.

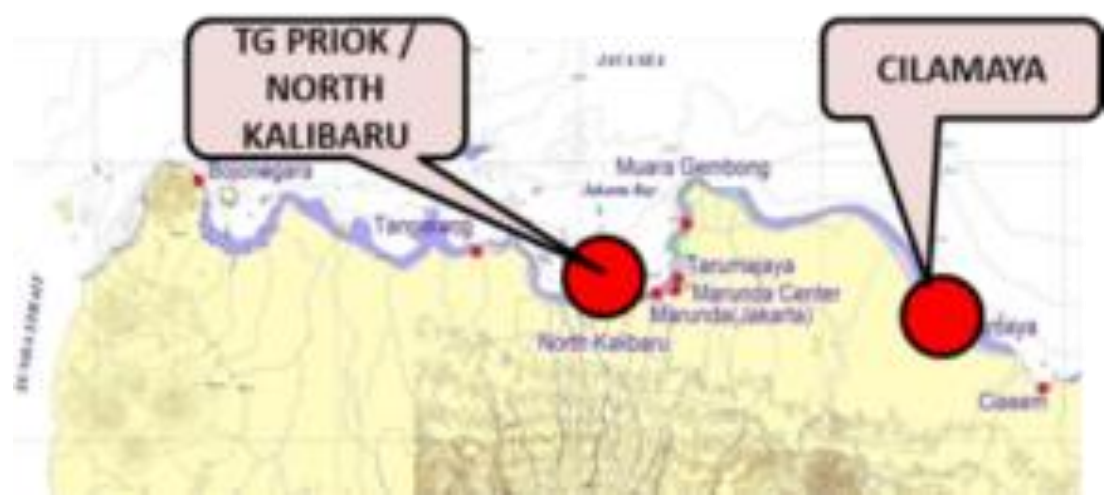

Figure 5. Location of Cilamaya Port

The Port of Cilamaya will be built in a dredged area of 173 ha, supported by 6 container berths with a capacity of 14.8 million TEUs and 1 multifunction berth with a total berth length of approximately 5,000 meters with a depth of -9 to -15.5 meters. This port is planned to serve container ships up to the $5^{\text {th }}$ generation. To support the operations of this 
port, it is important to plan for good accessibility. The access will come from road transport and railways.

To further support the logistics demands of Greater Jakarta for air transport, there is an dire need to build a multiple airport system. A multiple airport system is ideal to serve the airport capacity expansion needed to accommodate the increasing number of passengers and freight in the next 10 years, which is not possible to be served by Soekarno-Hatta Airport alone.

A Master Plan Study on Multiple-Airport Development for the Greater Jakarta Metropolitan Area suggests that passengers in Soekarno-Hatta Airport are projected to reach 57 million in 2015 (JICA, 2012b). It is almost 3 times the existing capacity. The estimated passenger growth has been analysed with careful consideration of several aspects, including airport functions, gross regional domestic product, low cost carrier services growth, as well as tourist arrivals.

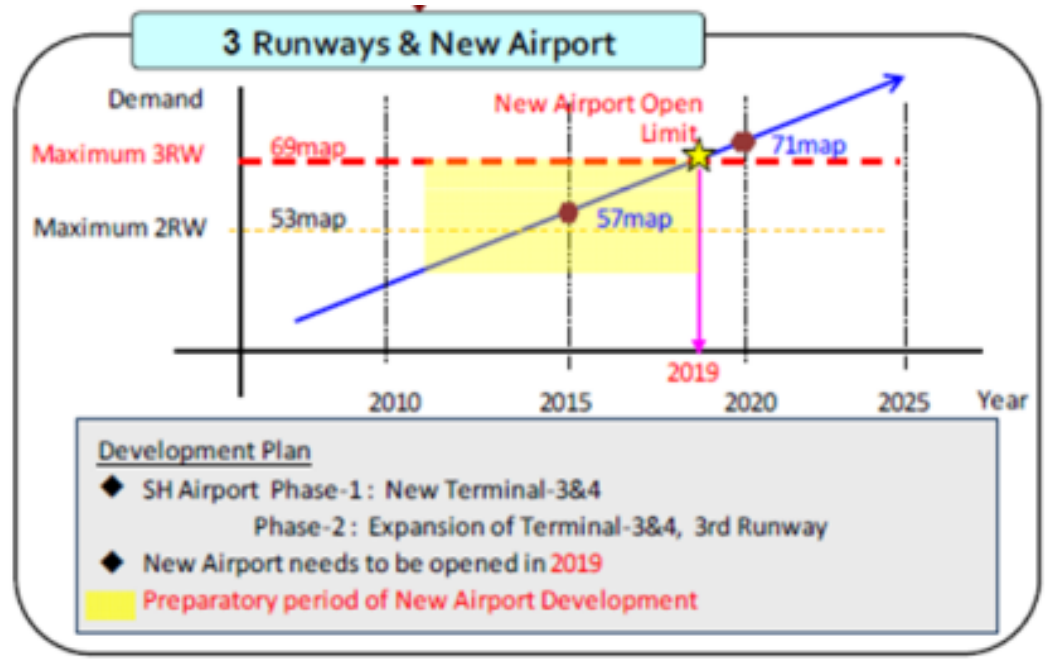

Figure 6. Demand Capacity Analysis for Runway

From Figure 6, it can be concluded that the capacity of the current two runways can only serve the passenger volume growth until 2015. A third runway is estimated to be sufficient until 2019. Further expansion capacity is needed to serve passengers after 2019. Expansion capacity can be made possible through the development of new airports in a multiairport system.

Moreover, the study also states that the total airport cargo in Soekarno-Hatta International Airport could reach 730,000 tons in year 2020. These include 334,000 tons of international cargo and 396,000 tons of domestic cargo. The size of air cargo volume in 2020 will be almost twice that of 2010. There are three suggested locations, all of which are located in the eastern part of Greater Jakarta. The study has incorporated comprehensive analyses including accessibility, airspace, existing supporting infrastructure, residential areas, and other geographical factors.

The new airport is expected to be operational by 2019, with a capacity of 30 million passengers/year and with two runways at the completion of the first phase. It is planned to expand this capacity up to 90 million passengers/year with four runways by 2040 . 


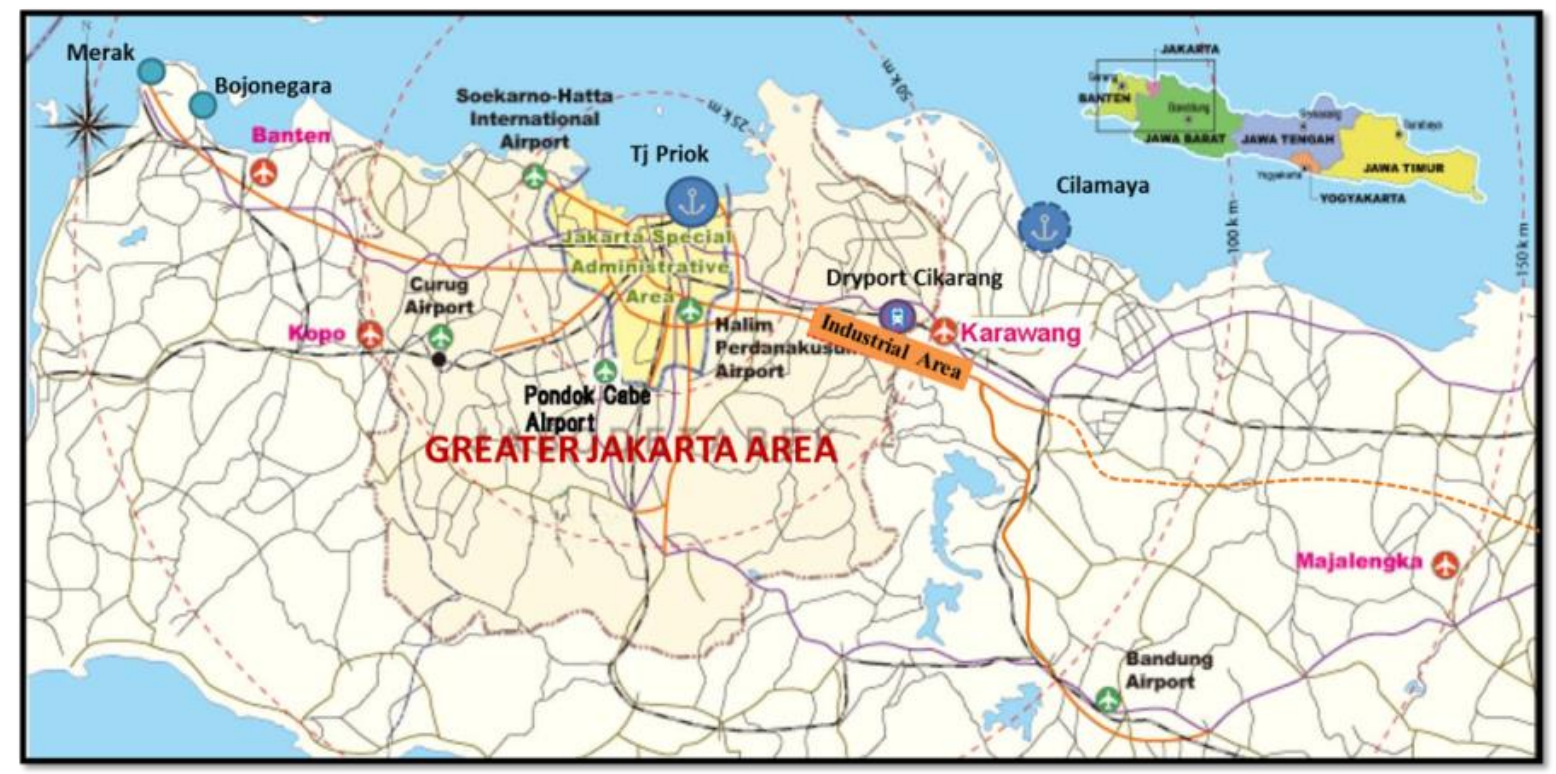

Figure 7. Transportation Infrastructure Development in Greater Jakarta

\section{CONCLUSION}

Development of transport infrastructure is vital to meet the country's growing logistics demand. Indonesia should integrate transportation hubs - seaports, airports, terminals and distribution centers - with the transport network and develop state-of-the-art logistics infrastructure for efficient distribution.

For the Greater Jakarta case study, a logistics network of industrial centers on the outskirts of Jakarta should be built for improved access to the congested port of Tanjung Priok, which suffers from traffic congestion outside the port. Moreover, other initiatives to improve dry port, build multiple-port and multiple-airport systems supported by access roads and railways to ports and airports will need to be implemented to guarantee a good flow of logistics, which will have a huge impact on Indonesia's competitive advantage to compete in the regional and global markets.

\section{REFERENCES}

Bassey, M. (2003). Case study research. Educational research in practice, 111-123.

Colliers International. (2012). Research \& Forecast Report: Jakarta Industrial Market.

David Wignal Associates. (2009). Tanjung Priok Short Term Development Review.

Jayaraman, V., Guide Jr, V. D. R., \& Srivastava, R. (1999). A closed-loop logistics model for remanufacturing. Journal of the operational research society, 497-508.

Giaglis, G. M., Minis, I., Tatarakis, A., \& Zeimpekis, V. (2004). Minimizing logistics risk through real-time vehicle routing and mobile technologies: Research to date and future trends. International Journal of Physical Distribution \& Logistics Management, 34(9), 749-764.

Himpunan Kawasan Industri Indonesia. (2012). Data of Industrial Location.

[http://www/hki-industrialestate.com]

Japan International Cooperation Agency (JICA), Master Plan Study on Port Development and Logistics in Greater Jakarta Metropolitan Area, Directorate General of Sea Transportation of Ministry of Transport of Republic of Indonesia, 2010.

Japan International Cooperation Agency (JICA), Jabodetabek Urban Transportation Policy Integration Project, Coordinating Ministry of Economic Affairs of Republic of Indonesia, 2011. 
Japan International Cooperation Agency (JICA), The Study on Master Plan for Establishing Metropolitan Priority Area, Ministry of Economic Affairs of Republic of Indonesia, 2012a.

Japan International Cooperation Agency (JICA), Master Plan Study on Multiple Airport Development for Greater Jakarta, Directorate General of Civil Aviation of Ministry of Transport of Republic of Indonesia, 2012.

Kasilingam, R. G. (1998). Logistics and transportation. Great Britain: Kluwer Academic Publishers.

Rushton, A. (Ed.). (2010). The handbook of logistics and distribution management. Kogan Page Publishers.

Stock, G. N., Greis, N. P., \& Kasarda, J. D. (2000). Enterprise logistics and supply chain structure: the role of fit. Journal of operations management, 18(5), 531-547.

Tellis, W. (1997). Application of a case study methodology. The qualitative report, 3(3), 117.

Vissak, T. (2010). Recommendations for using the case study method in international business research. The Qualitative Report, 15(2), 370-388. 